\title{
Mobile communications and belongings: Cape Verdeans in Portugal.
}

Elizabeth P. Challinor

\section{Abstract}

Use of the mobile phone to contact research subjects granted me privileged access to a body of poetic and humorous texts. The article examines Cape Verdeans' use of pass-forward text messages to express allegiances to different collective identities which provide information and inspiration for Cape Verdeans living in Portugal. They are used to foment and express solidarity between Cape Verdeans, Africans, Christians and Women. An analysis of their contents elucidates two aspects of belonging. Firstly, the personal and intimate which tends to the Self, in its yearnings for a better future and for intimate relationship, sought through religious communion and romance. Secondly, the political and discursive which foments community, imagined not only through nation, Pan-Africanism and gender, but also, beyond any such boundaries towards an all inclusive dimension of belonging, rooted in relations of solidarity.

Key words: Cape Verde; migration; collective identities; belonging; gender relations; mobile communication technologies 


\section{Introduction}

For someone to claim "I belong here" is a deceptively simple statement which the geographer Antonsich (2010) argues should not be taken at face value. Yet in the social sciences, "belonging" is frequently used without paying enough attention to what the concept stands for. Because it is a multi-dimensional concept, it is under-theorized, often conflated with identity (especially national and ethnic identity) but also used to refer to citizenship, to gender as well as to emotional attachments to places and groups (Antonsich 2010, p. 644-5). In his search for an analytical framework for conceptualising "belonging”, Antonsich (p. 6456) highlights two dimensions. The first is personal and intimate, feeling "at home" described as as a "symbolic space of familiarity, comfort, security and emotional attachment". The second is political - "a discursive resource which constructs, claims, justifies, or resists forms of socio-spatial inclusion/exclusion". These two dimensions are often intertwined and this is best captured in the hyphenated term "be-longing": in their aspirations for alternative modes of being, subjects may strive towards a belonging from which they are excluded, or they may long for a "lost" home. Adding a hyphen brings to light an existential dimension "that narrates and is narrated by the Self' (p. 647). The question Antonsich (p. 653) claims requires further research is whether a "community of belonging" can exist beyond a "community of identity". My aim is to address this question by elucidating different dimensions of Cape Verdean migrant belonging, through an analysis of text messages that circulate between members of a digital network providing information and inspiration for Cape Verdeans living in Portugal. The messages passed forward from one person to another express solidarity between Cape Verdeans, Africans, Christians and Women and it is these relations, rooted in solidarity which form the basis for conceiving of a "community of belonging" which goes beyond identity. 


\section{Context and methodology}

My interest in mobile communications (MC) arose out of a broader study on young Cape Verdean student's experiences of how unplanned pregnancy and motherhood impacted upon their sense of self (Challinor 2011a). Part of the study involved accompanying women in their medical appointments. The mobile phone was an indispensable tool for confirming the dates and times of appointments, often via written texts. As the research developed, I began to receive different kinds of messages from the mothers which corresponded to what Thompson (2009) calls "inspirational pass-forward messages". Their contents included poetic declarations of friendship, encouragement in the face of hardship and of unrequited love, playful criticism of men's behaviour and celebrations of Christmas, Easter, Women's Day, Cape Verdean Independence and Africa Day. The thirteen messages analysed in this article were received between 2008 and 2011.

Rather than conduct formal interviews, most discussions regarding MC usage took place informally ${ }^{1}$, slotted into the fieldwork of my wider study; in the waiting rooms of hospitals and health centres, in birthday parties and in the meetings of a self-help group organized within the ambit of an applied dimension of the study. The group was created in response to the expressed need for a means of facilitating mutual support and exchange between Cape Verdean student mothers (Challinor 2011b) and it is within this context of mutuality that I analyse the text messages.

The texts are not personal, in the sense that their original authors are anonymous. In some cases, I received the same text from various mothers as it circulated, presumably not only amidst Cape Verdeans, since those written in Portuguese may have originated from outside of the Cape Verdean digital network. None of the contents of the messages disclose 
personal, sensitive information and in all of the personal cases discussed, the names of individuals have been changed.

\section{Cape Verdeans in Portugal}

Cape Verdean identity is profoundly influenced by the country's lack of natural resources and its long history of extreme hardship, marked by famine, colonial neglect and migration (Carling and Batalha 2008, p. 17-18). Migration became a normalised survival strategy for the population that began during the colonial period. Following the abolition of slavery, an imbalanced distribution of the land, population growth, drought and frequent famines drove Cape Verdeans to emigrate, all over the world in increasingly large numbers, in search of better conditions (Carreira 1982, p. 18).

Migration to Portugal, most intense during the 1970s and 1980s, began in the mid1960s, partly in response to the shortage of cheap unskilled labour which, despite the growing Portuguese economy, had been drawn away to work in other European countries where wages were higher. The first labour migrants came from the rural communities of Cape Verde with hardly, if any, formal education. Although perceived to be hard-working, many of their descendents dropped out of school and hence failed to climb the social ladder to reach the middle-class mainstream of Portuguese society. Media representations of Cape Verdean youths as "delinquents" contributed towards their resistance to school and education (Batalha 2008, p. 61-3). This experience contrasts with that of youths in Cape Verde, for whom studying abroad symbolizes escape from their perceived lack of opportunities at home. Higher education is still valued as a way of avoiding labour emigration by increasing the chances of well-paid employment in Cape Verde (Carling and Äkesson 2009, p. 133). 
During the late colonial period, only a small elite minority of Cape Verdeans was able to study in Portugal (Batalha 2008). After independence, the number of Cape Verdean students in Portugal increased and with the availability of government grants, poorer parents were also able to send their children to study abroad. In the past decade, many students have come to study in training colleges.

Even the Cape Verdeans who came to study in Portugal, shared the same experience as the labour migrants who found that through a "conjunction of ethnicity, race, class and cultural practices" they had "gained a visibility never experienced in Cape Verde" (Batalha 2008, p. 65). In Porto, where I conducted my fieldwork, the African population is smaller and hence relatively less visible. Yet, when I asked a Portuguese student if she knew any Cape Verdean student mothers, she replied that she did not, adding that Cape Verdean students "tend to stick together".

Cape Verdean student mothers would usually put me in contact with more potential research subjects. One mother knew of a Cape Verdean student expecting a baby because she had given some of her own baby's clothes to her through a Cape Verdean friend; but she did not know her name and had never met her. Such anonymous relations of solidarity were also cultivated though the messages which circulated in the Cape Verdean digital network.

\section{Transnational digital connections}

Pre-paid phone cards enabled students to maintain closer ties with relatives in Cape Verde. MC were used to send messages and, on rare occasions, for those who could afford it, to speak to relatives back home. Many students reserved MC for communicating in Portugal, since connections and messages to Cape Verde were much more expensive. Some students had never owned a mobile phone until they came to Portugal. In Porto, nearly every Cape Verdean used the same operator that offered student promotional SIM cards which required a 
pre-payment of five Euros per month (instead of the standard ten Euros), entitling them to send free text messages to all other numbers of the same network in Portugal and to make free phone calls to users of the same promotional card. The sending of text messages is not free in Cape Verde. MC were consequently relatively accessible in Portugal, especially compared to internet services to which most students did not have access at home.

"How do I write that?" Text messaging in Creole

Language constitutes an important aspect of both the politics and the intimacies of "belonging". It can be used to make identity claims that distinguish "us" from "them" as well as to evoke warm feelings of "community" and "home" (Antonsich 2010, p. 648). Cape Verde's sociolinguistic condition of diglossia provides a window into the role of language in both the politics and emotions of "belonging".

Text messaging in Portugal has had an impact upon the way in which young Cape Verdean migrants relate to their mother tongue - a Portuguese based Creole - by increasing its usage in written form. Given their access to free messages, this was the first time many used the Creole language to communicate, in written form, on a regular basis. In Cape Verde, Creole is confined to oral communication; the official language is Portuguese, also used by school teachers in the classroom.

Portuguese and Creole occupy different positions in the Cape Verdean imagination. Portuguese is associated with formalities and legalities but also with colonial repression and exclusion. Creole has been made to embody "the shameful, the vulgar and the primitive", but it is also the language of humour, strong emotions and romance, embodying "the impenetrably intimate, the communal and the pleasurable" (Rego 2008, p. 152). 
Various students claimed that when they arrived in Portugal, they began by sending messages in Portuguese because they didn't know how to write in Creole. Then, gradually, they switched over. Texting in Creole may consequently be seen as a way of connecting with "the auto-biographical sphere...to generate a sense of feeling 'at home"” (Antonsich 2010, p. 648). The students learnt how to write by copying from the messages they received in Creole and also by writing based on how they spoke, often inventing the spelling of words. There were also influences from Portuguese text messages, such as using " $k$ " for the Portuguese "que" (what) and "fc" for the Portuguese "fica" (to stay). Some students claimed to receive messages in Creole that they did not always understand. Such was the case with the end of a pass inspirational message (see below) I received which read "Ses ta dexa dado rola" for which after various enquiries, only one mother offered a tentative translation; "deixar rolar na sexta feira" - "to allow (the message) to roll on Friday". "Sexta-feira" translates as Friday in Portuguese and " $\mathrm{x}$ " is often interchangeable with " $\mathrm{s"}$ in text messages; however, in the original text, "Ses" and "ta" were separated and consequently could also be translated as "if they let you" (se es ta dexa).

The illegibility of personal texts could also be intentional. Katia had developed a private code for writing in Creole to a group of friends. A young father wrote in accordance with the language variations of the receiver. He was a rare example of somebody who claimed to know how to write in Creole and was able to adopt the different island variations ${ }^{2}$ in his texts.

Whilst the Cape Verdean elite engage in an on-going debate of whether or how to officialise a standardised version of Creole, text messaging in Creole continues to produce new forms which add a digital dimension to the language's history of oral inventiveness. Since some of these forms are influenced by Portuguese, text messaging in Creole maintains the historical interplay between the two languages and may thus be analysed in the light of 
Gilroy's (1993) perspective upon how African traditions are constituted through, rather than despite, colonial contact.

\section{A pocket virtual support network}

The Cape Verdean community in Porto used text messages on a daily basis to circulate practical information related to daily living both in Portugal and in Cape Verde. On the one hand, it worked like the internet, creating the potential for "scaling-up", transcending immediate locations. The outburst of dengue fever in Cape Verde, in 2009, for example, resulted in the circulation of a text message recommending a particular brand of mosquito repellant, to be bought and sent to relatives back home: a continuation of the reciprocities that characterize transnational Cape Verdean social relations (Drotbohm 2009). On the other hand, the circulation of text messages between the Cape Verdean immigrant community helped to "scale-down", by unifying a dispersed minority community within a majority urban setting. A Cape Verdean Association, for example, used mobile text messages as the main means of informing its members of upcoming events in Porto.

The messages ${ }^{3}$ discussed below demonstrate how MC are used to express membership of a social digital network (Thompson 2009) that creates a sense of community, religious solidarity and "be-longing". For the purposes of my analysis, I define "be-longing" as a positioning of the Self between memories of past hardships and longings for a better future which involves looking inwards at how hardship has honed the Self and looking outwards, yearning for inclusion, unity, and intimate relationship.

The following texts which circulated on 11 April 2009 to mark Easter and on 22 December 2009 to celebrate Christmas were originally written in Portuguese. They express the sender's adherence to the majority Catholic faith in Portugal and in Cape Verde where it was introduced during the colonial period by the Portuguese. Mass in Cape Verde is usually 
celebrated in Portuguese although hymns are often sung in Creole. The coming together of African and Portuguese religious practices was actively promoted by the University Chaplaincy in Porto which organized an African mass once a month in which a small choir, comprised of African immigrants, sang hymns in several African languages from the former Portuguese colonies, including Cape Verdean Creole.

Easter...

Resurrection of the smile...Resurrection of the joy of living...Resurrection of love...Resurrection of friendship...Resurrection of the desire to be happy. That you may have all of this and much more... Holy Easter! Kisses ${ }^{4}$

Christmas, celebrated annually, is an opportunity to be born again, to open up a new aurora in our lives and a new place in our hearts. May you have a happy and holy Christmas full of light, determination and the will to be more. Happy Christmas! kisses ${ }^{5}$.

The emphasis upon becoming a better Christian is characteristic of many of the messages which urge the receiver to "be-long": to strive to be a better person in religious and/or social communion. The following message, written in Creole, forwarded anonymously to me on 15 August 2009, provides an example of this.

Before tears invade your eyes, remember that your smile is more beautiful..before you allow sadness to enter your heart remember that joy is a visitor who arrives without invitation..before you think that no-body is bothered about you, remember that I am always there, far or not far...today or tomorrow...daytime or night-time...Live life: the way God wants you to...always in your place...with whoever makes you happy...with your 
lessons...with your moralswith your errors.@@@ @ forget those who wish youharm@@@@@@youdon'tneed them@@@@@@@@@ take action instead of running away @ and remember:*life is only $1 *_{x} @$ ha ha ha....kisses ${ }^{6}$

It is not clear, from the text, whether the pledge of constant support is intended to come from a person or a deity; this blending of the human with the divine is also characteristic of the celebration of religious feasts in Cape Verde.

In the calendar of rural life, work, religion and leisure are intimately linked to a multidimensional conception of existence that is consubstantial with the feasts, to such a degree that it is sometimes difficult to establish whether what is being celebrated is a divinity, the life of the group, or even the latter's relations to its culture. However, there is a common feature which presides over these rural ceremonies, whether they are celebrated in the street or in the church - the desire for solidarity and fraternization (Lopes Filho 1995, p. 87-88, my translation).

The importance of valuing friendship in the midst of hardship is a recurrent theme. Consider how the following text, sent to me on 6 November 2009, by a young mother, expresses the sentiments of "be-longing". She had finished studying in Porto and had recently moved to live with the father of her child, three hundred kilometres away in Lisbon:

I learnt..That I hardly know anything, That I always needed to learn, That life is very short, And there is no time to lose! I realized. That not everything is possible, That sometimes it is difficult to smile, That life is hard, but I am 
not going to give up! I understood..That when I suffer, I will know, That

pain teaches us to live, That life is a long road, along which I will grow!

However, I realized...That when I have friends, I should never forget them.

Kisses $^{7}$

Personal advancement is historically associated with hardship and the need to make sacrifices. Hardships hone the self and their memory nourishes strivings for a better future; however, this cannot be a solitary journey since the Self is also constituted through interpersonal relations (Antonsich 2010, p. 647). Friendship, social and religious communion are often combined in a single message and sometimes in a playful manner. The following text, sent on 02 December 2010, also written in Portuguese, begins with a very typical Cape Verdean request to put up a friend in need of accommodation who then turns out to be Jesus. I initially thought it was a sincere request since a mother had recently asked me if her sister could live in my home for three months:

Hello, sorry to disturb it is very urgent! I have a friend who has come from very far away and he needs to stay somewhere. So, I indicated your home. He asks you to receive him and to love him. His name is Jesus Christ. Now, say quietly: you may enter lord, I need you, clean my heart with your blood and bless my family if you believe in God send this message to twenty people don't reject it and you will receive a miracle tomorrow ${ }^{8}$.

The promise of a miracle through forwarding on the message to others is another common feature providing an alternative, playful channel for a younger generation, that faces the challenges of living abroad, far from family support, to express traditional Cape Verdean magical-religious attitudes and beliefs. The creation of these superstitious digital rituals ${ }^{9}$ may 
be seen to evoke the religious syncretism characteristic of spiritual practices in Cape Verde (Lopes Filho 1995, p. 87-95). The text below, received on the 17 June 2009, could be interpreted as a digital substitute for the Catholic practice of confession before a priest.

\author{
Read quietly and return to me "Jesus I adore you and need you. I know I \\ haven't been as you would like me to, but come inside my heart now. Help \\ me to triumph without harming anyone, even myself". Send to 9 people \\ including who sent it to you and you will have 1 miracle tonight. Note: don't \\ ignore this, you will have 1 surprise! ${ }^{10}$
}

The text was sent to me by Luisa, a young student mother who had suffered emotional and financial problems during her pregnancy and who had since opted for the painful decision to send her child to be looked after by family, in Cape Verde, whilst she worked and completed her studies in Porto.

Whether the moral and religious messages that were written in Portuguese originated from within or outside the Cape Verdean community, their circulation in the Cape Verdean digital network suggests that they were appropriated by their senders as a meaningful way of expressing sentiments of solidarity, in order to create a symbolic space of emotional support.

The offer of moral support through a digital network may be interpreted within the wider context of traditional forms of cooperative work in rural Cape Verde, known as djuntamon (the joining of hands) in which networks of neighbours and friends are activated to carry out specific tasks, especially in agriculture. Beyond its role in mobilising and exchanging unpaid labour, djunta-mon has traditionally been valued for fomenting social cohesion, solidarity and mutuality (Couto 2001, p. 146-7). 
The texts written in Creole, discussed below, demonstrate how language can be used to create both a sense of political belonging and of emotional attachment to people and places. Creole is often described by linguists as a result of the mixture of Portuguese and African mainland languages. Yet, this mixing process was not devoid of politics or power:

Kriolu can be said to have originated from the convergence (or clash) of two opposing movements. The first toward collaboration - between coloniser and colonised - between master and slave, between Portuguese, Cape Verdean and African slaves, between slaves and the Catholic Church. The second movement, in contrast, was geared toward differentiation, whether in the form of exclusion, resistance or subversion. Kriolu was located paradoxically, both within and outside of the Portuguese language (Rego 2008, p. 147).

The use of Creole does not just signal a personal, intimate attachment to "home" it also makes a political statement about the relationship between identity, place and power. The following text, written in Creole, celebrating Independence Day for Cape Verde (5 July), sent on 5 July 2009, serves as a discursive resource to justify the liberation of Cape Verde from the power of colonial rule and to champion the Cape Verdean national identity - an "imagined community" (Anderson 1983) of political belonging.

Hey, we drink, we shout, we scream, we howl, we salute Cape Verde, for 34 years we have stopped being donkeys, we became free and independent like a bird. Long live Amílcar Cabral ${ }^{11}$, long live Cape Verde. Pass this message on to all cape Verdeans. ${ }^{12}$ 
In this text Cape Verde's independence is celebrated through an explosion of sound. I asked the mother who sent it to me to translate the words "djata" and "pupa". She explained that they both meant to shout, but that "pupa" which I have translated as "howl", was a more vulgar word used by people in the countryside that usually refers to animals.

Cape Verdeans are known to talk loudly, according to the president of a Cape Verdean local council whom I accompanied during his visit to three training colleges in Porto in December 2009. The president held a meeting with the Cape Verdean students in each college. In order to facilitate their integration into Portuguese society, he gave them advice on how to behave. The president passed on the suggestion that a teacher in Cape Verde used to give to his pupils, that, if they wanted to talk loudly, they should go to the woods and shout their heads off and then when they had finished, they could return to town and to school where they should lower their voices.

On a first reading, the council president's "civilizing" advice on how to behave as exemplary citizens appears to reproduce colonial representations of the "savage African" (who runs wildly into the woods, although there are not many of these in Cape Verde) which included a "scale of being" upon which "the African was assigned a particularly base position: he marked the point at which humanity gave way to animality" (Comaroff and Comaroff 1991, p. 35).Yet, the president also gave a cultural justification for raising the voice in conversation, by explaining that in Cape Verde to talk quietly is a sign that you are telling secrets (implying that it is rude to do so in front of others). The desire for an independent Cape Verde was no longer a secret. This boisterous message commemorated the resistance which had put an end to the silent sufferings imposed by colonial rule.

The explosion of sound evoked in the text also contrasts with the mood of "typical" Portuguese parties, as described to me by a Cape Verdean mother (Challinor forthcoming). 
The way in which the Portuguese do parties is different. They sit down, everybody talks and everybody likes to listen to what the other person is saying...the Portuguese prefer silence and talking. Not Cape Verdeans! There is music there is dance, people talk as well, but it is totally different...

Although the most prominent markers of Cape Verdean identity are the country's music and Creole language, the mutual relations of solidarity that developed in response to hardship constitute an equally important characteristic of Cape Verdean sociality; so much so, that, in the text below, sent on 5 July 2010, anyone who shares in the celebrations is welcome to become Cape Verdean.

Lift up your arms and shout out your freedom, shout independent people, shout combatants of our land! Long live 5 July, pass this message on to all Cape Verdeans and to whoever desires to become Cape Verdean to celebrate the 35 years of our independence. ${ }^{13}$

Half way through the last phrase, the original text switches from Creole to Portuguese with the words whoever desires to become Cape Verdean, thus transcending the history of colonial repression and exclusion by promoting and celebrating unfettered inclusion: nationbuilding and transnationalism are made to complement each other. Rego (2008) argues that the spanning of boundaries is crucial to the very existence of Cape Verde:

Cape Verde's situation of deprivation and poverty does not allow it to be a self-sustaining and autonomous nation. However, this has not precluded it 
from imagining itself as an independent nation moving towards a utopian future. Forever reminded of a fundamental lack by its very name (Green Cape), Cape Verde imagined itself as independent from its colonisers, but also unavoidably related to many other peoples and nations (Rego 2008, p. 157).

It is within this context that Cape Verde may be seen as a "community of belonging" that stretches the boundaries beyond Cape Verdean identity. Further evidence can be found in the following message, sent to me by Luisa on the day of Africa - 25 May (2009) - that not only expresses a Pan-African identity of group solidarity but also evokes gender solidarities through the celebration of motherhood.

$$
\begin{aligned}
& \text { A-Amoroso (Loving) } \\
& \text { F-Forte (Strong) } \\
& \text { R-Rico (Rich) } \\
& \text { I-Incrível (Incredible) } \\
& \text { C-Carinhoso (Afectionate) } \\
& \text { A-Alegre (Cheerful) }
\end{aligned}
$$

Beautiful continent, Sweet Land, Sweet Sea, sweet everything..Today may Africa be honoured, like a mother who suffers but never loses Hope in her children... You are the Hope of this AFRICA! Send this message to all Africans. $^{14}$

The poignancy of this personification of Africa, for young Cape Verdean single mothers living in Portugal, is evident in the way the message transformed their role as mothers to their 
babies into that of ambassadors for a whole continent and thus also helped, in a symbolic way, to break their isolation.

It is noteworthy that Africa is only recovered as a female presence half way through the text since the adjectives are in the masculine. One explanation for this could be that the Portuguese text was influenced by Creole which is not a gendered language. The failure to begin the text with adjectives in the feminine could also be seen as an indication of how women only become visible in their reproductive roles. Rodrigues (2003) argues that most historical accounts of Cape Verdean society that refer to "miscegenation" and the "mixing" between colonisers and colonized, fail to explore the creative role women played in the transformation of Portuguese culture and language into new Creole creations.

The portrayal of Africa as a mother may also be analysed in the light of the Comaroffs' (1991, p. 38) examinations of colonial and missionary representations of Africa as female, embedded in gender ideologies in which reason and intelligence were masculine properties. The choice of words to characterize Mother Africa - loving, affectionate, and cheerful - is mostly linked with emotions which is also evident in the following text (written in Portuguese), sent on international woman's day (8 March 2009):

A woman has strengths that startle men. She is able to bear problems and heavy burdens. She bears happiness, love and opinions. She smiles when she feels like shouting, sings when she feels like crying, cries when she is happy and laughs when she is scared. Her love is unconditional. She only commits 1 error: sometimes she forgets how much she is worth. Send this to all the beautiful women you know. Happy WOMAN'S day ${ }^{15}$.

By playfully highlighting women's worth, this text suggests that the role of women is undervalued in Cape Verdean society. The claim that women also bear opinions may be read 
as an indirect request for their points of view to be taken seriously, although it still situates a woman's knowledge in the emotional body rather than in the reasoning mind.

The command to forward the message to beautiful women is playfully taken up in the following text, (sent in Portuguese), on International Woman's Day, 8 March 2010, revealing the purely fun side of pass-forward inspirational messages:

Today is the world day of good-looking women!!!! So send this sms to the best looking woman you know. I know you are already thinking of me, but not any more please!!! I have already received over a hundred today!!!

What are you laughing at? That's how it is when you are good-looking:) Kisses $^{16}$

Humour and encouragement are also employed to express the ambiguous sentiments that women feel, caught between their criticisms of male behaviour and their desires for intimate relationships with men. The following section discusses how MC usage mediates intimate gender relations between Cape Verdean students.

Mobile communications and gender relations

It is hard to love in secret, to suffer for someone who doesn't deserve it, to walk past someone you love pretending not to know them, but it is even harder to love without being loved. So love who loves you and forget who didn't want you and when the past comes back, know how to love and be happy. Pass this message on to 10 people in the next 15 minutes the person you love, will call you or will send you an sms saying "I love you"...It is not worth keeping this message...Send it back! Ses ta dexa dado rola ${ }^{17}$ ! 
This message regarding unrequited love is gender free and urges the reader to put a halt to the constant re-positioning of the self between painful memories of the past and hopeful yearnings for the future, by living the present. Yet, it does not banish the past, for, should it come back - presumably this refers to rekindled interest from a former lover - then the implicit message is one of acceptance and forgiveness.

The membership of a digital social network opens up new channels for acquiring sexual partners. Although it enhances the freedom that young female students experience living beyond the control of family, MC usage also serves as a mechanism of control for both women and men, who are suspicious of each other's fidelity; for example, through the secret reading of a partner's personal text messages. The power struggles over access to the contacts and private messages of partner's mobile phones were related to me in several cases.

Francisca met the father of her child, Oswaldo, who was studying in a different town, through an accidental digital encounter caused by the swapping of mobile phones. Oswaldo had been persuaded to temporarily exchange his more expensive mobile phone with a friend who was visiting Cape Verde. Cape Verdeans returning home are often under pressure to display outward signs of their material success abroad (Carling and Äkesson 2009). The use of mobiles, as a "display item" (Thompson 2009, p. 365) or status symbol for the emigrant returning to visit families in Cape Verde is part of a longer tradition of imbuing products from abroad with a special status. Something as insignificant as a bar of soap used to gain a special aura if it came from America (Meintel 1984).

Francisca's mobile number was recorded on the friend's phone (rather than on his SIM card) and so Oswaldo sent her a text message, in the belief that he was communicating with a friend who shared the same name. They exchanged messages and then began to speak with 
each other over the phone, finally agreeing to meet up one day in Porto. Francisca described their encounter in an interview I conducted, in the following terms:

When he sent the message, I replied "No, it's not me, no". Then he rang and I asked him where he was from and we spoke in Portuguese. So I asked if he didn't speak Creole and he said "Yes, I am from Cape Verde too”. We spoke in Creole. Then the next day, he rang again, apologized, and explained that he had exchanged mobiles. We chatted, we became friends, and we spoke every day until we met up.

Francisca had finished her studies a few years ago and was now employed as a domestic worker. When Oswaldo finished his final university examinations, he moved to Porto and they lived together with their newborn baby, for a short period of time. Although it had been an unplanned pregnancy, Oswaldo had been very supportive at the beginning, reassuring her that, despite being a poor student, "a child is always welcome."

After a period of six months, without contacting Francisca, I discovered that they had split up. She told me Oswaldo was "cool" (fixe) and that he only had one defect: "running after women". She described how he would help in the house, pick up the baby from the nanny and stay with him at home until she arrived from work. Francisca claimed that they had a close relationship but then he began to disappear for nights on end. She asked him if he was seeing another woman and he denied this. But one night, after having disappeared again for a couple of days, he returned and slept with his mobile phone under his pillow. She thought this was strange because they had always been very open about accessing each others' mobile phones. So, whilst he was asleep, she took the mobile from under his pillow and reading his text messages, discovered that he was having a relationship with another woman. Francisca eventually decided to contact the other woman and when Oswaldo found out he was furious 
and days later, left her to go and live in Lisbon. Francisca rang him on several occasions, in failed attempts to persuade him to return to Porto; if not to live with her, at least to be closer to his son.

The day he left, Francisca was at work and he went by the nanny to say good-bye to his eight month old son. He brought a toy mobile for a present and left it with the nanny. "It is the only thing he ever bought for him", Francisca exclaimed. When I commented upon the symbolism of having chosen to buy his son a mobile phone, Francisca retorted, "He gave a mobile to his son for him to ring up his girlfriends". Her sense of humour provides an example of a toying with gender inequalities that appears to simultaneously challenge and acknowledge the inevitability of male promiscuity.

There is a widespread belief in Cape Verde regarding the "natural disposition" of men to have more than one woman. (Äkesson 2009, p. 387). Male sexual freedom contrasts with the restrictions placed upon girls: the more partners they are known to have had, the less desirable they become. In a conversation I had with a young student mother, in Porto, about contraception use in rural Cape Verde, she explained that only the boys carry condoms with them, for if a girl were to be seen with one, she would be called "another name". This name is spelled out in the text message received below in which men are simultaneously criticized and desired:

What a boy can do to you:

1 Lie

2 Make you dream

3 Cheat on you

4 Take advantage of you; 
And then we are the whores! In 3 days time you will have a surprise. A boy

is going to prove that he likes you, if you break the chain two embarrassing things will happen to you: send to 10 GIRLS $S^{18}$.

The playful criticism, of how boys treat girls, echoes women's criticisms of "partial

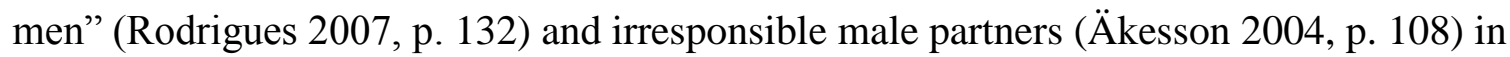
Cape Verde. It also challenges the inequality in Cape Verdean conceptions of masculinity and femininity in which promiscuity is only damaging to a woman's reputation. Despite these criticisms of male behaviour, the text ends with a teasing promise that still leaves women hoping for the men to make the next right move.

Written in Portuguese (21 July 2009), the text was sent to me by a young mother who had given birth to her first baby just nine days before. She had also sent it to Katia, who expressed her surprise, when we all met up a few weeks later that she had forwarded on this message to her but, had not announced the birth of her baby. The contents of pass-forward messages are anonymously produced and effortlessly forwarded on to friends and acquaintances, allowing the sender to maintain minimal contact, without having to make the effort to write personalized texts. Consider the following message, written in Portuguese, sent to me on 31 December 2011, by the Cape Verdean mother who had moved to Lisbon:

"There is a place where everything is possible...Where love is true...Where you sleep a sleep of peace...Where the flowers have a special smell...And hugs come accompanied with a sweet taste...This place is called the heart...It is in this place that I keep the people I don't always see, but whom I never forget...;);) good year 2012. Big hug for all the family Big kisses ${ }^{19}$

\section{Conclusion}


Through use of the mobile phone to contact research subjects, I was incorporated into a digital network that granted me privileged access to a body of poetic and humorous texts. Their contents serve to promote political belongings to an independent Cape Verdean nation and to a Pan-African collective identity, whilst also expressing sentiments of "be-longing" which I define as a honing of the self through past hardships and a longing for sociality and emotional attachment expressed through religious beliefs and romantic aspirations. The desire for intimate relations with the opposite sex is tempered by a playful challenging of gender inequalities that unites women as a category but still leaves them hoping for a "miracle" in which men will make the next right move. In other words, more important than allegiances cultivated through national belonging, religious belief or gender conflicts, are those which span boundaries through reciprocity and solidarity. A telling example of this is to be found in the comment made to me by a young Cape Verdean student couple ${ }^{20}$, shocked at the lack of care for their elderly Portuguese neighbour by her three adult children who had left home, that they would have to take their neighbour back with them to Cape Verde. The notion that appropriate care was readily available in Cape Verde suggests that whilst reciprocity and solidarity are at the root of the spanning of boundaries beyond "communities of identity", they are also, paradoxically, constitutive features of Cape Verdean identity.

\section{Acknowledgements}

Research funded by the Foundation for Science and Technology (FCT). I am grateful to the anonymous reviewers for their insightful comments.

ELIZABETH P. CHALLINOR is Associate Researcher at the Centre for Research in Anthropology (CRIA), University of Minho (UM). 
ADDRESS: CRIA, Av. Forças Armadas, Ed. ISCTE, 1649-026 Lisboa, Portugal. Email:

e.p.challinor@gmail.com

\section{Notes}

${ }^{1}$ There is one exception where the issue of MC usage arouse naturally during a recorded interview in which the interviewee's detailed account of migrant motherhood included a description of how she had met her partner.

${ }^{2}$ Cape Verdean Creole is divided into two main types: sampadjudo - the Creole spoken in the Windward Islands and badiu - spoken in the Leeward Islands.

${ }^{3}$ Apart from the automatic capitalisation that occurs in translation - such as I for "eu" - the original capitalisations and punctuations have been reproduced in translation.

${ }^{4}$ Pascoa...Ressureição do sorriso...Ressureição da alegria de viver...Ressureição do amor...Ressureição da amizade... Ressureição da vontade de ser feliz. Que tenhas tudo isso e muito mais...Santa Pascoa! Bjx

${ }^{5} \mathrm{O}$ natal, celebrado anualmente, é uma oportunidade de nascermos de novo, de abrirmos uma nova aurora nas nossas vidas e um novo lugar nos nossos corações. Que tenhas um feliz e santo natal cheio de luz, determinação e vontade de ser mais. Boas festas! bj

${ }^{6}$ Antis di lágrima invadi bu odjo, lembra ma bu sorriso é mas bonito..antis di bu dexa tristeza entra na bu coracon lembra ma alegria é um visita ki ta tchiga sem convite..antis di bu atcha ma ninguém ka sta preocupa ku bo, lembra ma mi sta sempre li, longi ou ka longi...hoji ou manha...di dia ou di noiti...Leba vida: cima deuz kre...smp na di bo...ku kenha ki ta dexau feliz...ku bu licon...ku bu moral...ku bus erroz.@@@@skeci kez ki tadesejaumal@@@@@@@buka mestez@@@@@@@@@@ bu agi em vezdi fugi @ i lembra:*vida é so $1 * x @$ heeheh....bjs

${ }^{7}$ Aprendi..Que não sei quase nada, Que sempre precisei de aprender, Que a vida é muito curta, E não há tempo a perder! Percebi. Que nem tudo é possível, Que as vezes é difícil sorrir, Que a vida é dura, mas eu não vou desistir! Entendi..Que quando sofro, eu vou saber, Que a dor ensina a viver, Que a vida é um longo caminho a percorrer, ao qual irei crescer! Contudo, Compreendi...Que quando se tem Amigos, jamais os deverei esquecer. Bjos

${ }^{8}$ Ola, desculpa incomodar é muito urgente! Tenho um amigo que veio de muito longe e precisa ficar nalgum sitio. Sendo assim, indiquei a tua casa. Pede que o recebas e o ames. O nome dele é Jesus Cristo. Agora, diz baixinho: podes entrar senhor, eu preciso de ti, limpa meu coração com teu sangue e abençoa a minha familia se acreditas em Deus envia esta mensagem a 20 pessoas não o rejeites e vais receber um milagre amanhã.

${ }^{9}$ An example of traditional Cape Verdean rituals is on the seventh day after the birth of a baby, in which a series of practices are carried out to protect the baby from witches (See Lopes Filho 1994:33-36).

${ }^{10}$ Le baixinho e devolve-me "Jesus adoro-te e preciso de ti. Sei que não tenho sido como tu queres, mas vem para dentro do meu coração agora. Ajuda-me a vencer sem prejudicar a ninguém, nem a mim mesmo. Envia a 9 pessoas incluindo a quem te enviou e terás 1 milagre esta noite. Obs: não ignores, terás 1 surpresa!

${ }^{11}$ Leader of the liberation struggle for the independence of Guinea Bissau and Cape Verde from Portugal.

${ }^{12}$ You, nu bebi, nu grita, nu djata, nu pupa, nu da viva cv, 34 ano ki nu ka sta burro mas, nu birra livre e independente sima um passaro. Viva Amílcar Cabral, viva Cabo Verde. Passa msg pa tudo berdiano.

${ }^{13}$ Labanta braço bu grita bu liberdad, grita povo independent, grita combantent d nox terra! Viva 5 de Julho, paxa a msm pra todos os caboverdianos e pra kem deseja converter-se cabo-verdiano para festejar os 35 anos da nossa libertad.

${ }^{14}$ Belo continente, Doce Terra, Doce Mar, doce tudo..Que hoje Africa seja homenageada cmo mãe que sofre mas nunca perde a Esperança nos seus filhos...Tu és a Esperança desta AFRICA! Envie esta ms'g a todos Africanos.

${ }^{15}$ Uma mulher tem forças q espantam os homens. É capaz de suportar problemas e pesados fardos. Detem felicidade, amor e opiniões. Sorri quando lhe apetece gritar, canta quando lhe apetece chorar, chora quando está feliz e ri quando tem medo. $\mathrm{O}$ seu amor é incondicional. Comete apenas 1 erro: por vezes esquece o quanto vale. Envia a tds as mulheres lindas q conheces. Feliz dia da MULHER! 
16. "Hoje e o dia mundial das mulheres giras!!!! Por isso manda esta sms a mulher mais gira que conheces. Eu sei que já estas a pensar em mim, mas por favor mais não!!! Hoje já recebi mais de cem!!! Tas-te a rir de que?! E o que da ser-se gira:) Bjs" (Accents missing in original text).

${ }^{17}$ É duro amar escondido, sofrer por quem não merece, passar perto de quem se ama fingindo que não se conhece, mas o mais duro ainda é amar sem ser amado. Por isso ama quem te ama e esquece quem não te quis e quando o passado voltar, sabe amar e ser feliz. Passa esta mensagem a 10 pessoas nos próximos 15 minutos a pessoa que tu amas, te ligará ou te mandará uma sms a dizer "amo-te"...beijinhos....Não vale ficar com ela...Devolve! Ses ta dexa dado rola.

${ }^{18} \mathrm{O}$ que um rapaz te pode fazer:

1 Mentir

2 Fazer te sonhar

3 Engana-te

4 Aproveitar-se de ti;

E depois nós é que somos as putas! Dentro de 3 dias vais ter uma surpresa, um rapaz vai te provar que ele gosta de ti se partires a corrente duas coisas vergonhosas vão te acontecer, envia a 10 RAPARIGAS.

19 "Existe um lugar onde tudo é possível... Onde o amor é verdadeiro...Onde se dorme um sono de paz... Onde as flores tem um cheiro especial...E os abraços vem acompanhados de um doce sabor...Este lugar chama-se coração... É neste lugar que eu guardo as pessoas que nem sempre vejo, mas que nunca esqueço...;);) bom Ano 2012. Abraço grande para toda a familia Beijocas.

${ }^{20}$ Resident in a smaller, northern town where I am currently conducting research. 


\section{References}

Anderson, B., 1983. Imagined Communities: Reflections on the Origin and Spread of Nationalism. London: Verso.

Antonsich, M., 2010. Searching for Belonging - an Analytical Framework. Geography Compass 4 (6), 644-659.

Äkesson, L., 2009. Remittances and Inequality in Cape Verde: the Impact of Changing Family Organization. Global Networks 9 (3), 381-398.

Äkesson, L., 2004. Making a Life: Meanings of Migration in Cape Verde. Thesis (PhD). Goteborg University.

Batalha, L., 2008. Cape Verdeans in Portugal, In: L. Batalha and C. Jorgen, eds. Transnational Archipelago: Perspectives on Cape Verdean Migration and Diaspora. Amsterdam: Amsterdam University Press, 61-72.

Carling, J. and Äkesson, L., 2009. Mobility at the Heart of a Nation: Patterns and Meanings of Cape Verdean Migration. International Migration 47 (3), 123-155.

Carreira, A., 1977. The People of the Cape Verde Islands: Exploitation and Emigration. ed. Christopher Fyfe, trans. 1982. London: Hurst and Company Limited.

Challinor, E., (forthcoming). To be or not to be? Managing the labyrinths of migrant motherhood for Cape Verdean Women in Portugal. In M. Unnithan and S. K. Khanna, eds. Migration and the Politics of Reproduction and Healthcare: Place, Identity and Cultures of Migrant Family-Making. Oxford: Berghahn Books.

Challinor, E., 2011a. Cape Verdean Migrants and Extended Mothering. In M. Walks and N. McPherson, eds. Mothering: Anthropological Perspectives. Bradford, ONT: Demeter Press, 196-208. 
Challinor, E., 2011b. Researching Ethnicity, Identity, Subjectivity: Anything but the Four Lettered Word. Ethnic and Racial Studies http://www.tandfonline.com/doi/abs/10.1080/01419870.2011.593641\#preview.

Comaroff, J. and Comaroff J., 1991. Of Revelation and Revolution, vol. 1, Chicago: University of Chicago Press.

Couto Ferreira, C., 2001. Estratégias Familiares e Subsistências Rurais em Santiago de Cabo Verde. Lisboa: Instituto da Cooperação Portuguesa, Ministério dos Negócios Estrangeiros.

Drotbohm, H., 2009. Horizons of long-distance Intimacies: Reciprocity, contribution and disjuncture in Cape Verde. History of the Family 14, 132-149.

Gilroy, P., 1993. The Black Atlantic: Modernity and Double Consciousness. London: Verso. Lopes Filho, J., 1995. Cabo Verde: Retalhos do Quotidiano. Lisbon: Editorial Caminho. Meintel, D., 1984. Race, Culture and Portuguese Colonialism in Cabo Verde. Syracuse, New York: Maxwell School of Citizenship and Public Affairs, Syracuse University. Rego, M., 2008. Cape Verdean Tongues: Speaking of "Nation" at Home and Abroad. In: L. Batalha and C. Jorgen, eds. Transnational Archipelago: Perspectives on Cape Verdean Migration and Diaspora. Amsterdam: Amsterdam University Press, 145-160.

Rodrigues, I.P. B.F., 2007 As Mães e os seus Filhos dentro da Plasticidade Parental: Reconsiderando o Patriarcado na Teoria e na Prática. In M. Grassi and I. Évora, eds. Género e Migraçoes Cabo-Verdianas. Lisbon: Imprensa de Ciências Sociais, 123-146.

Rodrigues, I.P.B.F., 2003. Islands of Sexuality: Theories and Histories of Creolization in Cape Verde. International Journal of African Historical Studies 36 (1), 83-103.

Thompson, E. C., 2009. Mobile Phones, Communities and Social Networks among Foreign Workers in Singapore. Global Networks 9 (3), 359-380. 